\title{
Role of Increased Cytosolic Free Calcium in the Pathogenesis of Rabbit Proximal Tubule Cell Injury and Protection by Glycine or Acidosis
}

Joel M. Weinberg, Julie A. Davis, Nancy F. Roeser, and Manjeri A. Venkatachalam*

Division of Nephrology, Department of Internal Medicine, University of Michigan and Veterans Administration Medical Center, Ann Arbor, Michigan 48109; and *Departments of Pathology and Medicine, University of Texas Health Science Center at San Antonio, San Antonio, Texas 78284

\begin{abstract}
To assess the role of increased cytosolic free calcium $\left(\mathrm{Ca}_{\mathrm{f}}\right)$ in the pathogenesis of acute proximal tubule cell injury and the protection afforded by exposure to reduced medium $\mathrm{pH}$ or treatment with glycine, fura-2-loaded tubules were studied in suspension and singly in a superfusion system. The $\mathrm{Ca}^{2+}$ ionophore, ionomycin, increased $\mathrm{Ca}_{\mathrm{f}}$ to micromolar levels and rapidly produced lethal cell injury as indicated by loss of lactate dehydrogenase to the medium by suspended tubules and accelerated leak of fura and failure to exclude Trypan blue by superfused tubules. Decreasing medium $\mathrm{Ca}^{2+}$ to $100 \mathrm{nM}$ prevented the ionomycin-induced increases of $\mathrm{Ca}_{4}$ and the injury. Reducing medium $\mathrm{pH}$ from 7.4 to 6.9 or adding $2 \mathrm{mM}$ glycine to the medium also prevented the cell death, but did not prevent the increase of $\mathrm{Ca}_{\mathrm{f}}$ to micromolar levels. Cells treated with 1799, an uncoupler of oxidative phosphorylation which produced severe adenosine triphosphate (ATP) depletion, did not develop increases of $\mathrm{Ca}_{\mathrm{f}}$ until just before loss of viability. Preventing these increases of $\mathrm{Ca}_{\mathrm{f}}$ with $100 \mathrm{nM} \mathrm{Ca}^{2+}$ medium did not protect 1799-treated cells. Reduced $\mathrm{pH}$ and glycine protected 1799-treated cells without ameliorating the increases of $\mathrm{Ca}_{\mathrm{f}}$. These data demonstrate the toxic potential of increased $\mathrm{Ca}_{f}$ in the proximal tubule and show that $\mathrm{Ca}_{\mathrm{f}}$ does sharply increase prior to loss of viability in an ATP depletion model of injury, but this increase does not necessarily contribute to the outcome. The potent protective actions of decreased $\mathrm{pH}$ and glycine allow the cells to sustain increases of $\mathrm{Ca}_{\mathbf{f}}$ to micromolar levels in spite of severe, accompanying cellular ATP depletion without developing lethal cell injury. (J. Clin. Invest. 1991. 87:581-590.) Key words: adenosine triphosphate • fura- $2 \cdot$ ionomycin • kidney • uncoupler
\end{abstract}

\section{Introduction}

The normal tight regulation of cytosolic free calcium $\left(\mathrm{Ca}_{\mathrm{f}}\right)^{1}$ levels allows their use as intracellular signals and prevents damaging effects of uncontrolled activation of $\mathrm{Ca}^{2+}$-dependent degradative processes (1). Disruption of intracellular $\mathrm{Ca}^{2+}$ homeo-

Address reprint requests to Dr. Weinberg, Nephrology Division, Room 1560, MSRB II, University of Michigan Medical Center, Ann Arbor, MI 48109-0676.

Received for publication 15 June 1990 and in revised form 24 September 1990

1. Abbreviations used in this paper: $\mathrm{Ca}_{\mathrm{f}}$, cytosolic free calcium; $\mathrm{LDH}$, lactate dehydrogenase.

J. Clin. Invest.

(c) The American Society for Clinical Investigation, Inc. $0021-9738 / 91 / 02 / 0581 / 10 \quad \$ 2.00$

Volume 87, February 1991, 581-590 stasis accompanying lethal cell injury has been well documented (2-12). For these reasons, it has been widely discussed whether loss of $\mathrm{Ca}^{2+}$ homeostasis is an important process, possibly the central mediator, that determines the transition to lethal cell injury, or is simply a late secondary consequence of loss of plasma membrane integrity that results from other more primary events $(2-7,12)$.

Delineation of whether substantial increases of $\mathrm{Ca}_{\mathrm{f}}$ consistently precede cell death and are modified by protective maneuvers is essential for establishing a pathogenetic role. Despite the availability and increasing application during the past several years of fluorescent indicators allowing assessment of $\mathrm{Ca}_{\mathrm{f}}$, conflicting conclusions have been reached about the timing and extent of changes in $\mathrm{Ca}_{\mathrm{f}}$ secondary to hypoxia or other adenosine triphosphate (ATP)-depleting maneuvers.

Early, reversible increases of $\mathrm{Ca}_{\mathrm{f}}$ have been reported for anoxic, cultured monkey kidney tubule cells (LLC-MK M $_{2}$ (13) and for cultured dog kidney tubule cells (MDCK) treated with metabolic inhibitors (14). However, the relationship of these changes to cell injury was not determined. In primary cultures of rabbit proximal tubule cells, large increases of $\mathrm{Ca}_{\mathrm{f}}$ produced by ionomycin were promptly followed by cell death, but ATPdepleting inhibitors produced only moderate early increases of $\mathrm{Ca}_{\mathrm{f}}$ and lethal cell injury was delayed well beyond the time during which $\mathrm{Ca}_{\mathrm{f}}$ measurements were made (15). Another divalent cation ionophore, A23187, did not substantially injure freshly isolated proximal tubules, however, $\mathrm{Ca}_{\mathrm{f}}$ was not measured (16). Single hepatocytes in primary culture treated with cyanide plus iodoacetate didn't show increases of $\mathrm{Ca}_{\mathrm{f}}$ until just before lethal cell injury and preventing these increases by lowering medium $\mathrm{Ca}^{2+}$ to $<1 \mu \mathrm{M}$ did not affect the timing of cell death $(17,18)$, but a similarly treated hepatoma cell line showed substantial early increases of $\mathrm{Ca}_{\mathrm{f}}$ and buffering these increases ameliorated injury (19). Prelethal increases of $\mathrm{Ca}_{\mathrm{f}}$ have been reported for both freshly isolated (20) and cultured (21) myocytes.

Proximal tubule cells are an important site of damage during ischemic and toxic forms of acute renal failure (22). Recent studies of hypoxic and metabolic inhibitor-induced injury to isolated proximal tubules have described potent protection against these lesions by reduced $\mathrm{pH}$ and the small, neutral amino acids, glycine and alanine (23-30). The work reported in this article was designed to clarify the role of altered $\mathrm{Ca}_{\mathrm{f}}$ in the pathogenesis of proximal tubule cell injury and protection by reduced $\mathrm{pH}$ and glycine. Our results show that ionomycininduced increases of $\mathrm{Ca}_{\mathrm{f}}$ are highly toxic. Increases of $\mathrm{Ca}_{\mathrm{f}}$ to micromolar levels also occur consistently before death in proximal tubules that are energy-deprived by treatment with an uncoupler of mitochondrial oxidative phosphorylation. However, such increases of $\mathrm{Ca}_{\mathrm{f}}$ are not necessary for damage to occur in uncoupler-treated tubules. Furthermore, we show that reduced $\mathrm{pH}$ and glycine provide protection in spite of ionomy- 
cin and uncoupler-induced increases of $\mathrm{Ca}_{\mathrm{f}}$ equivalent to those seen in unprotected tubules.

\section{Methods}

Isolation of tubules. Proximal tubules were isolated from kidney cortex of male New Zealand white rabbits $(\simeq 2.5 \mathrm{~kg}$; Shankin's Rabbitry, Warren, MI) by collagenase digestion and isopycnic centrifugation on Percoll gradients $(23,25)$. Final tubule pellets were resuspended at a concentration of 5-7.5 mg of tubule protein $/ \mathrm{ml}$ in ice-cold medium gassed with $95 \% \mathrm{O}_{2} / 5 \% \mathrm{CO}_{2}$. The medium contained (in millimolar) $105 \mathrm{NaCl}, 2.6 \mathrm{KCl}, 25 \mathrm{NaHCO}_{3}, 2.4 \mathrm{KH}_{2} \mathrm{PO}_{4}, 1.25 \mathrm{CaCl}_{2}, 1.2 \mathrm{MgCl}_{2}$, $1.2 \mathrm{MgSO}_{4}$, and, for most studies, 2.5 probenecid. ${ }^{2}$ The incubation medium also included (in millimolar) 5 glucose, 4.5 sodium lactate, 1 alanine, and 10 sodium butyrate (solution $\mathrm{A}$ ).

Loading of tubules with fura-2/acetoxymethylester (AM). To load cells with fura-2 (Molecular Probes, Inc., Eugene, OR) for measurements of $\mathrm{Ca}_{\mathrm{f}}$ in single superfused tubules, $25 \mu \mathrm{l}$ of a $1.0 \mathrm{mM}$ stock solution of fura-2/AM in dimethylsulfoxide was vigorously mixed into $500 \mu \mathrm{l}$ of medium without tubules and the mixture was then added to $4.5 \mathrm{ml}$ of the tubule suspension to produce a $5 \mu \mathrm{M}$ final concentration. The siliconized, 25-ml Erlenmeyer flask containing these tubules was gassed with $95 \% \mathrm{O}_{2} / 5 \% \mathrm{CO}_{2}$, sealed, and gently shaken in a water bath at room temperature for $60 \mathrm{~min}$. The tubules were then pelleted by centrifugation at $30 \mathrm{~g}$, washed twice in ice-cold medium containing (in millimolar) $110 \mathrm{NaCl}, 3.5 \mathrm{KCl}, 1.0 \mathrm{KH}_{2} \mathrm{PO}_{4}, 1.25 \mathrm{CaCl}_{2}, 1.0 \mathrm{MgCl}_{2}$, and $25 \mathrm{Na}-\mathrm{Hepes}, \mathrm{pH} 7.2$, and were resuspended in this medium (solution B). 500- $\mu$ l aliquots of suspension were then uniformly applied to 25-mm diam no. 11/2 glass coverslips (Nicholson Precision Instruments, Gaithersburg, MD) that had been precoated with poly-D-lysine. The coverslips were kept in covered $35-\mathrm{mm}$ culture dishes at $4^{\circ} \mathrm{C}$ for a minimum of $20 \mathrm{~min}$ to allow maximal settling and adherence of tubules before study.

To prepare fura-loaded tubules for studies in suspension, a similar loading procedure was followed except $50-\mathrm{ml}$ aliquots of tubules were incubated in $250-\mathrm{ml}$ flasks during the loading period. At the end of the fura-loading procedure tubules were washed with solution B and dispensed as $5-\mathrm{ml}$ aliquots into $25-\mathrm{ml}$ flasks that were kept ice cold until use.

Some studies of tubules in suspension were done using probenecidfree medium and tubules that had not been fura-loaded. After preparation, these tubules were resuspended in a solution of identical composition to solution A except for the omission of probenecid. 5-ml aliquots of the tubule suspension were placed in 25-ml flasks, gassed with $95 \%$ $\mathrm{O}_{2} / 5 \% \mathrm{CO}_{2}$, sealed, and kept ice cold until use.

Measurement of $\mathrm{Ca}_{f}$ in superfused tubules. A coverslip with adherent tubules was mounted in a Dvorak-Stotler culture chamber (Nicholson Precision Instruments) and perfusion at $0.82 \mathrm{ml} / \mathrm{min}$ from a $20-\mathrm{ml}$ syringe using a pump (model 975, Harvard Apparatus Co., Inc., South Natick, MA) was started immediately with a solution similar to solution A except that the alanine concentration was reduced to $0.3 \mathrm{mM}$ and the sodium butyrate concentration was reduced to $5 \mathrm{mM}$ (solution C). These concentrations were chosen to approximate those present when tubules in suspension studies were treated with experimental agents after a preincubation period during which substrate metabolism was occurring.

The chamber was mounted on the stage of an inverted microscope (Nikon Inc., Garden City, NY) connected to a CM-2 spectrofluorometer system (Spex Industries, Inc., Edison, NJ) utilizing the DM 3000

2. Probenecid was used to inhibit compartmentalization and extrusion of fura-2 $(31,32)$. Although sufficient fura-2 loading for assessment of $\mathrm{Ca}_{\mathrm{f}}$ could be achieved in the absence of probenecid, the organic acid transport inhibitor greatly increased sensitivity of the system and facilitated the use of fura leakage from tubules as an index of injury (detailed in Results). The effects of probenecid to increase fura loading were dose dependent between 0.5 and $2.5 \mathrm{mM}$, the practical limit of its solubility in our solutions at $37^{\circ} \mathrm{C}$. computer and software. The chamber and microscope stage were kept at $37^{\circ} \mathrm{C}$ using an Air Stream incubator (Nicholson Precision Instruments). The tubule was viewed using a CF FLUOR $100 \times$ Oil/Iris lens (Nikon, Inc.) and was illuminated alternately with $340-$ and $380-\mathrm{nm}$ excitation signals for 0.33-s intervals through 0.4- $\mathrm{mm}$ slits ahead of the chopper, an ND0.3 neutral density filter (Omega Optical, Brattleboro, VT) and a DM 400 dichroic mirror (Nikon, Inc.). Emitted light was collected through the dichroic mirror then transmitted via a narrow band $510 \mathrm{~nm}$ filter (510DF40, Omega Optical) in the microscope and a 500FS40 filter (Spex Industries, Inc.) in the photomultiplier assembly to the fluorometer photomultiplier.

Mounting the chamber on the microscope stage, locating and positioning a tubule using visible light from the microscope, and making final adjustments to perfusion syringes and experimental parameters on the computer generally required 5-7 min during which the coverslip was perfused with solution $\mathrm{C}$ at $37^{\circ} \mathrm{C}$. An additional period of at least $100 \mathrm{~s}$ of perfusion with solution $\mathrm{C}$ was then recorded before introducing experimental maneuvers. Tubules $\mathrm{Ca}_{\mathrm{f}}$ 's were consistently stable during this 100 -s perfusion and for at least $30 \mathrm{~min}$, the maximal duration studied in this series of experiments, unless experimental agents or the calibration procedure induced changes.

Experimental agents were introduced by switching to a perfusion syringe containing a solution of the desired composition. At the end of the last desired experimental maneuver, tubules were either subjected to a calibration procedure or were stained with Trypan blue. The calibration procedure consisted of perfusion with a nominally $\mathrm{Ca}^{2+}$-free form of solution $\mathrm{C}$ that also contained $2.5 \mathrm{mM}$ EGTA and $15 \mu \mathrm{M}$ ionomycin (Calbiochem-Behring Corp., La Jolla, CA), followed by solution $\mathrm{C}$ supplemented with $\mathrm{Ca}^{2+}$ to a concentration of $3.5 \mathrm{mM}$ and 15 $\mu \mathrm{M}$ ionomycin, then by solution C containing $200 \mu \mathrm{M} \mathrm{MnCl}_{2}$. Each of the calibration solutions was continued long enough to achieve a stable response (see experimental tracing figures in Results). Trypan blue exclusion was assessed by perfusion with a solution consisting of a $100 \%$ $\mathrm{O}_{2}$-gassed 50:50 mixture of 0.4\% Trypan blue in normal saline (Gibco Laboratories, Grand Island, NY) and solution B.

To determine $\mathrm{Ca}_{f}$, the values of the 340 - and $380-\mathrm{nm}$ signals at the end of the $\mathrm{MnCl}_{2}$ perfusion were subtracted to correct for intrinsic autofluorescence and other $\mathrm{Ca}^{2+}$-independent fluorescence in the system (33). $\mathrm{Ca}_{\mathrm{f}}$ was calculated from the $340 / 380$ ratios using the equation: $\left[\mathrm{Ca}^{2+}\right]_{\mathrm{f}}=\left(K_{\mathrm{d}} \cdot S_{\mathrm{f}} / S_{\mathrm{b} 2}\right) \cdot\left(R-R_{\min }\right) /\left(R_{\max }-R\right)$, where $R$ is the ratio at any point; $R_{\min }$ is the ratio achieved during perfusion with EGTA and ionomycin in $\mathrm{Ca}^{2+}$-free solution $\mathrm{C} ; R_{\max }$ is the ratio achieved during perfusion with ionomycin in $3.5 \mathrm{mM} \mathrm{Ca}^{2+}$ solution $\mathrm{C} ; S_{\mathrm{n} 2}$ is the absolute value of the corrected 380 signal at $R_{\min } ; S_{\mathrm{b} 2}$ is the absolute value of the corrected 380 signal at $R_{\max } ; K_{\mathrm{d}}$ is $224 \mathrm{nM}(34){ }^{3}$

3. Fura-2/AM can be hydrolyzed in mitochondria as well as cytosol (35). The predominant cytosolic localization of the fura providing a $\mathrm{Ca}^{2+}$-sensitive signal in our system was established by studies in which we monitored the $\mathrm{Ca}^{2+}$-sensitive signal from fura-loaded tubules that were first perfused with $20 \mu \mathrm{M}$ digitonin in a $100 \% \mathrm{O}_{2}$-gassed, $37^{\circ} \mathrm{C}$ solution consisting of (in millimolar) $115 \mathrm{KCl}, 1.0 \mathrm{KH}_{2} \mathrm{PO}_{4}, 1.00$ $\mathrm{MgCl}_{2}, 5$ sodium succinate, $25 \mathrm{Na}-\mathrm{Hepes}, \mathrm{pH} 7.4,1.3 \mu \mathrm{M}$ rhodamine 123 , and free $\mathrm{Ca}^{2+}$ buffered to $100 \mathrm{nM}$ with EGTA until the digitonininduced leak of cytosolic fura- 2 was complete. Then perfusion was switched to an identical solution except for the presence of $1 \mu \mathrm{M}$ free $\mathrm{Ca}^{2+}$ for $5 \mathrm{~min}$, followed by observation of the tubule for rhodamine 123 localization at $490-\mathrm{nm}$ excitation, $520-\mathrm{nm}$ emission. Tubules treated in this fashion accumulated and retained rhodamine in their mitochondria during the full sequence of perfusions, indicating that mitochondrial membrane potential had been maintained. Despite this, no $\mathrm{Ca}^{2+}$-dependent fura signal was detected when $1 \mu \mathrm{M} \mathrm{Ca}^{2+}$ was introduced after the digitonin-induced leak of cytosolic fura. Since $1 \mu \mathrm{M}$ $\mathrm{Ca}^{2+}$ should have led to mitochondrial $\mathrm{Ca}^{2+}$ uptake in the presence of an adequate mitochondrial potential (36), the lack of a fura signal reflecting this uptake argues against a significant mitochondrial contribution to the $\mathrm{Ca}^{2+}$-sensitive fura signal of intact tubule cells in this system. 
The use of an internal calibration procedure and separate determination of autofluorescence for each tubule provided highly reproducible estimates of $\mathrm{Ca}_{\mathrm{f}}$ in the large number of tubules studied for this manuscript. No correction for medium fura- 2 was required because the dye was promptly removed by the perfusion system. Moreover, even if fura was deliberately included in the perfusion medium at micromolar concentrations, it contributed very little relative to the signal emanating from loaded tubules because of the fine plane of focus at $100 \times$.

Measurement of viability and metabolic parameters of fura-loaded tubules in suspension. Cold 5-ml aliquots of fura-loaded tubules suspended in solution B were pelleted at $30 \mathrm{~g}$, resuspended in solution A, gassed with $95 \% \mathrm{O}_{2} / 5 \% \mathrm{CO}_{2}$, and placed in the metabolic shaker for a 15-min preincubation. Then, experimental additions were made, and flasks were regassed and returned to the metabolic shaker for $15 \mathrm{~min}$ of experimental incubation before sampling for metabolic and structural parameters.

Measurement of viability and metabolic parameters of unloaded tubules in suspension. Flasks containing tubules in solution A without probenecid were incubated at $37^{\circ} \mathrm{C}$ for $30 \mathrm{~min}$ in the metabolic shaker. Then, experimental additions were made, and flasks were regassed and returned to the metabolic shaker for 7.5 or $15 \mathrm{~min}$ of incubation before sampling.

Analytical methods. Intracellular $\mathrm{K}^{+}$was measured by atomic absorption spectroscopy in tubules separated from their medium by centrifugation through bromododecane (Aldrich Chemical Co., Milwaukee, WI) (23). ATP was determined by HPLC on trichloroacetic acid extracts (23). Lactate dehydrogenase (LDH) was measured in the medium before and after the addition of $0.1 \%$ Triton X-100 as described (25). Protein was measured by the Lowry method (37).

Reagents. Reagents were obtained from Sigma Chemical Co. (St. Louis, MO) unless otherwise indicated. 1799, 2,6-dihydroxy$1,1,1,7,7,7$-hexafluoro-2,6-bis(trifluoromethyl)heptan-4-one[bis(hexafluoroacetonyl)acetone, a nonfluorescent uncoupler of mitochondrial oxidative phosphorylation $(38,39)$, was provided by Dr. Peter Heytler (DuPont Co., Wilmington, DE). 1799 and ionomycin were delivered from $100 \times$ absolute ethanol stocks. 1799 was used at $20 \mu \mathrm{M}$, a concentration which maximally stimulated respiratory rates of suspended tubules in preliminary experiments. Ionomycin was initially used at a concentration of $10 \mu \mathrm{M}$, but later studies were done with $15 \mu \mathrm{M}$ to assure maximal effects in experiments using $100 \mathrm{nM} \mathrm{Ca}^{2+}$ medium where increases of $\mathrm{Ca}_{\mathrm{f}}$ could not be used to monitor activity of the ionophore. All other experimental and calibration additions were delivered from $\geq 100$-fold concentrated aqueous stocks or were predissolved. $100 \mathrm{nM} \mathrm{Ca}^{2+}$ media were prepared by addition of EGTA to the standard media based on calculations using software developed by Fabiato (40) and checked by measuring fluorescence of fura pentapotassium salt added to medium in the absence of tubules.

Statistics. Data from multigroup experiments were analyzed statistically by analysis of variance for repeated measure designs. Individual group comparisons were then made using the Neuman-Keuls test for multiple comparisons (PC ANOVA, Human Systems Designs, Northridge, CA). Two group studies were assessed using paired or unpaired $t$ tests as appropriate. Comparisons of dye leakage and increases of $\mathrm{Ca}_{\mathrm{f}}$ to micromolar levels among groups were made by $\chi^{2}$ analysis.

\section{Results}

Effects of 1799, ionomycin, glycine, and pH 6.9 medium on suspended tubules. Loading of tubules with fura for $60 \mathrm{~min}$ at room temperature in the presence of probenecid and subsequent washing, cold incubation, then reincubation at $37^{\circ} \mathrm{C}$ for experiments did not adversely affect tubule cell viability or metabolic parameters (Table I). As compared to values for tubule preparations studied without fura loading or probenecid (references 25-27 and Table II), LDH release from control preparations was modest and excellent cellular ATP and $\mathrm{K}^{+}$levels were
Table I. Effects of Fura-Loading Procedure and of $10 \mu \mathrm{M}$ Ionomycin (ION), 1799, Glycine, and pH 6.9 on LDH Release, ATP, and $\mathrm{K}^{+}$in Fura-loaded Tubules

\begin{tabular}{|c|c|c|c|}
\hline & LDH & ATP & $\mathrm{K}^{+}$ \\
\hline & $\%$ free & \multicolumn{2}{|c|}{$n m o l / m g$ protein } \\
\hline End fura loading & $10.6 \pm 3.5$ & $7.30 \pm 0.20$ & $366.4 \pm 21.1$ \\
\hline End cold wash & $5.1 \pm 1.4$ & $5.27 \pm 0.41$ & $291.8 \pm 12.4$ \\
\hline $30 \mathrm{~min}$. control-early & $5.5 \pm 1.6$ & $8.93 \pm 0.35$ & $325.8 \pm 5.5$ \\
\hline $30 \mathrm{~min}$. control-late & $7.6 \pm 1.9$ & $8.43 \pm 0.14$ & $331.5 \pm 23.2$ \\
\hline ION & $34.9 \pm 4.4^{*}$ & $3.58 \pm 1.21^{*}$ & $224.7 \pm 29.5^{*}$ \\
\hline ION, $2 \mathrm{mM}$ glycine & $12.7 \pm 1.9^{* \neq}$ & $2.55 \pm 0.69^{*}$ & $162.6 \pm 9.8^{*}$ \\
\hline ION, pH 6.9 & $10.6 \pm 1.3^{* \neq}$ & $5.04 \pm 0.78$ & $267.0 \pm 16.3^{*}$ \\
\hline 1799 & $31.2 \pm 4.4^{*}$ & $0.51 \pm 0.02 * 1$ & $82.6 \pm 9.4^{* 1}$ \\
\hline 1799, 2 mM glycine & $7.9 \pm 1.1^{\ddagger}$ & $0.54 \pm 0.04 * 1$ & $71.9 \pm 10.6^{* 8}$ \\
\hline 1799, pH 6.9 & $8.7 \pm 1.1^{\ddagger}$ & $0.92 \pm 0.12^{* 1}$ & $108.2 \pm 13.2^{* 1}$ \\
\hline ION + 1799 & $62.2 \pm 1.9^{* 1}$ & $0.40 \pm 0.06^{* 1}$ & $126.0 \pm 26.0^{* 1}$ \\
\hline \multicolumn{4}{|l|}{$\mathrm{ION}+1799,2 \mathrm{mM}$} \\
\hline glycine & $19.8 \pm 1.6^{* \neq !}$ & $0.54 \pm 0.04^{* 1}$ & $80.5 \pm 12.2^{* 1}$ \\
\hline ION + 1799, pH 6.9 & $20.0 \pm 3.8^{* \neq !}$ & $0.73 \pm 0.10^{* 1}$ & $128.4 \pm 22.7^{* 1}$ \\
\hline
\end{tabular}

Each value is the mean $\pm \mathrm{SE}$ of results from four experiments. "End fura loading" indicates the end of the 60-min room temperature incubation with fura. "End cold wash" values are for samples taken after the fura loading solution was removed by washing and samples were aliquoted into separate flasks for experiments. 30-min control samples were taken from flasks rewarmed beginning almost immediately after the wash procedure (early) or after $\sim 100 \mathrm{~min}$ of cold storage (late experiment).

* $P<0.01$ vs. 30 -min time control.

${ }^{\ddagger} P<0.01$ vs. corresponding condition not treated with glycine or $\mathrm{pH} 6.9$.

${ }^{3} P<0.05$ vs. corresponding group treated with ionomycin alone. I $P<0.01$ vs. corresponding group treated with ionomycin alone.

achieved in tubules reincubated at $37^{\circ} \mathrm{C}$ immediately after the wash as well as in tubules kept cold for $100 \mathrm{~min}$. prior to reincubation (Table I).

$10 \mu \mathrm{M}$ ionomycin and $20 \mu \mathrm{M} 1799$ each increased LDH release from fura-loaded tubules suspended in probenecid-containing medium during $15 \mathrm{~min}$ of incubation relative to time controls (Table I). The combination of ionomycin +1799 had a greater effect than either agent alone. This LDH release was strongly ameliorated by $2 \mathrm{mM}$ glycine or lowering the medium $\mathrm{pH}$ to 6.9 during toxin exposure.

In tubule preparations incubated in probenecid-free medium and not loaded with fura-2 (Table II), LDH release produced by ionomycin and ionomycin +1799 was very similar to that seen in the fura-loaded tubules, while LDH release produced by 1799 alone was somewhat greater than that seen in fura-loaded tubules. The general pattern of protective effects was similar to the fura-loaded tubules in that LDH release secondary to 1799 alone, ionomycin alone, or both agents in combination was significantly ameliorated by glycine or reduction of the medium pH to 6.9. In contrast to the observations with fura-loaded tubules where pH 6.9 and glycine were equivalently protective against all three insults, $\mathrm{pH} 6.9$ in this series of experiments with unloaded tubules provided less protection than glycine against ionomycin +1799 . The experiments with 
Table II. LDH Release and ATP Levels of Unloaded Tubules Treated with Ionomycin, 1799, Glycine, and pH 6.9

\begin{tabular}{|c|c|c|c|c|c|c|}
\hline & \multicolumn{3}{|c|}{ Percent free LDH } & \multicolumn{3}{|c|}{ ATP } \\
\hline & $\begin{array}{l}\text { No further } \\
\text { additions }\end{array}$ & $2 \mathrm{mM}$ glycine & pH 6.9 & $\begin{array}{l}\text { No further } \\
\text { additions }\end{array}$ & $2 \mathrm{mM}$ glycine & pH 6.9 \\
\hline & & & & \multicolumn{3}{|c|}{ nmol/mg protein } \\
\hline Time control & $12.6 \pm 0.9$ & $12.5 \pm 0.6$ & $9.7 \pm 0.6$ & $7.69 \pm 0.26$ & $7.63 \pm 0.34$ & $7.45 \pm 0.44$ \\
\hline 1799 & $51.5 \pm 1.3$ & $14.1 \pm 0.5^{8}$ & $13.3 \pm 0.2^{\S}$ & $0.28 \pm 0.01$ & $0.26 \pm 0.02$ & $0.48 \pm 0.01$ \\
\hline $10 \mu \mathrm{M}$ ION & $36.4 \pm 6.5$ & $19.9 \pm 2.4^{\S}$ & $13.4 \pm 1.1^{8}$ & $5.61 \pm 0.47$ & $5.23 \pm 0.51$ & $6.85 \pm 0.18^{\ddagger 1}$ \\
\hline $10 \mu \mathrm{M}$ ION + 1799 & $64.1 \pm 2.5$ & $20.5 \pm 0.9^{8}$ & $32.9 \pm 3.4^{81}$ & $0.33 \pm 0.02$ & $0.51 \pm 0.03$ & $0.54 \pm 0.04$ \\
\hline $15 \mu \mathrm{M}$ ION & $56.6 \pm 1.9^{*}$ & $20.4 \pm 1.6^{8}$ & $14.6 \pm 1.1^{8}$ & $2.33 \pm 0.25^{*}$ & $2.76 \pm 0.45^{*}$ & $6.41 \pm 0.23^{51}$ \\
\hline $15 \mu \mathrm{M}$ ION + 1799 & $61.6 \pm 3.4$ & $22.8 \pm 2.3^{8}$ & $44.9 \pm 3.4^{\ddagger 1}$ & $0.38 \pm 0.01$ & $0.46 \pm 0.01$ & $0.49 \pm 0.01$ \\
\hline
\end{tabular}

Values are means \pm SE of results from three experiments. All toxin-treated groups except for $1799,2 \mathrm{mM}$ glycine, and 1799 , pH 6.9 had significantly higher percent free LDH values than the corresponding time controls $(P<0.05$ or better $)$. All toxin-treated groups except for $10 \mu \mathrm{M}$ ionomycin at $\mathrm{pH} 6.9$ had significantly lower ATP levels than corresponding time controls $(P<0.01)$. All 1799-treated groups had significantly lower ATP levels than corresponding groups that did not receive $1799(P<0.01)$. Abbreviation: ION, ionomycin. ${ }^{*} P<0.01$ vs. corresponding $10 \mu \mathrm{M}$ ionomycin group. ${ }^{\ddagger} P<0.05$ vs. corresponding no further additions group. ${ }^{\S} P<0.01$ vs. corresponding no further additions group. I $P<0.01$ vs. corresponding glycine-treated group.

unloaded tubules also included a comparison of effects of 10 and $15 \mu \mathrm{M}$ concentrations of ionomycin (Table II). $15 \mu \mathrm{M}$ ionomycin induced more $\mathrm{LDH}$ release than $10 \mu \mathrm{M}$ ionomycin when tubules were treated with ionomycin alone, but not when they received ionomycin +1799 .

In the fura-loaded tubules, tubule cell ATP and $\mathrm{K}^{+}$levels were significantly decreased by ionomycin, 1799, and the combination of both agents (Table I). The effects of ionomycin were less severe than those of 1799 . With ionomycin alone, glycine tended to promote the decreases of ATP and $\mathrm{K}^{+}$, whereas pH 6.9 tended to ameliorate them, but the differences were not statistically significant. In the presence of 1799 , there were no differences of ATP or $\mathrm{K}^{+}$among untreated, glycinetreated and $\mathrm{pH}$ 6.9-treated tubules. Changes of ATP levels in the unloaded tubules (Table II) were similar to those found in the fura-loaded tubules except that the effects of $\mathrm{pH} 6.9$ medium to ameliorate ionomycin-induced decreases of ATP were statistically significant.

Effects of 1799, ionomycin, and glycine on $\mathrm{Ca}_{f}$, dye retention, and vital dye exclusion in single superfused tubules. Fig. 1 illustrates the behavior of $\mathrm{Ca}_{\mathrm{f}}$ in a typical control tubule. In this experiment, the raw 340- and 380-nm signals show a gradual downward drift before any manipulations (e.g., see bottom tracing of Fig. 3), although many tubules showed no drift at all. $\mathrm{Ca}_{\mathrm{f}}$, determined from the ratio of the 340- and 380-nm signals, was stable during the $1,000 \mathrm{~s}$ of control perfusion. Then the superfusion solution was changed to one consisting of $15 \mu \mathrm{M}$ ionomycin $+2.5 \mathrm{mM}$ EGTA in a nominally $\mathrm{Ca}^{2+}$-free medium, thus maximally decreasing $\mathrm{Ca}^{2+}$-dependent fluorescence of fura $\left(R_{\min }\right)$. Subsequent perfusion with medium containing 15 $\mu \mathrm{M}$ ionomycin $+3.5 \mathrm{mM} \mathrm{Ca}^{2+}$ produced a maximal $\mathrm{Ca}^{2+}$-sensitive fura signal $\left(R_{\max }\right)$ with large reciprocal changes at the two wavelengths; then fura fluorescence was quenched by perfusion with $200 \mu \mathrm{M} \mathrm{MnCl}_{2}$ to provide a background autofluorescence value for the tubule. In 65 tubules which underwent the full calibration procedure, basal $\mathrm{Ca}_{\mathrm{f}}$ before any experimental manipulations averaged $( \pm \mathrm{SE}) 77.7 \pm 6.4$.

A representative tubule treated with $10 \mu \mathrm{M}$ ionomycin during the experimental period is shown in Fig. 2. $\mathrm{Ca}_{\mathrm{f}}$ increases sharply after introduction of the ionomycin and remains elevated. However, the individual 340 - and $380-\mathrm{nm}$ signals show
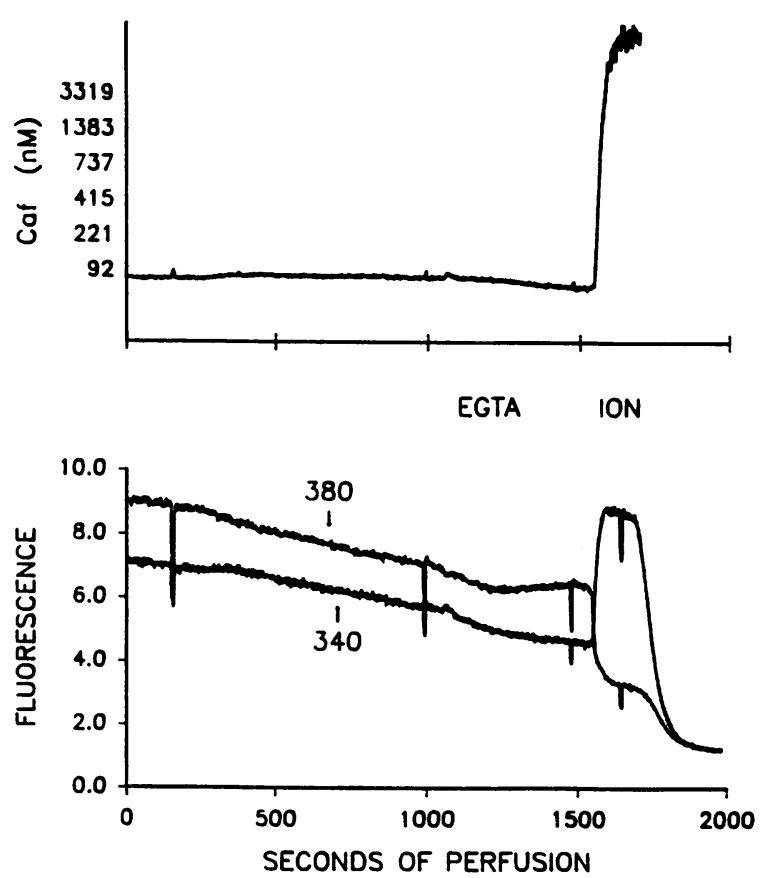

Figure 1. Behavior of $\mathrm{Ca}_{\mathrm{f}}$ in superfused tubules under control conditions. The bottom tracing shows the raw $340-$ and $380-\mathrm{nm}$ signals. Fluorescence units are counts per second $/ 10^{4}$. The $380-\mathrm{nm}$ signal in this experiment started at a higher fluorescence than the 340-nm signal. The top tracing shows the ratio of the two signals presented on a scale indicating the calculated $\mathrm{Ca}_{\mathrm{r}}$. Sharp parallel deflections in both tracings are artifacts resulting from syringe changes. As in all subsequent experiments, there was $\sim 100 \mathrm{~s}$ of initial perfusion with control medium. In this experiment, perfusion was then changed to a second syringe with control medium for $900 \mathrm{~s}$ followed by the calibration procedure consisting of sequential perfusion with $15 \mu \mathrm{M}$ ionomycin +2.5 mM EGTA in nominally $\mathrm{Ca}^{2+}$-free medium (labeled $E G T A$ on the tracing), $15 \mu \mathrm{M}$ ionomycin in medium containing $3.5 \mathrm{mM} \mathrm{Ca}^{2+}$ (labeled ION on tracing), and medium containing $200 \mu \mathrm{M} \mathrm{MnCl}_{2}$ (not labeled on tracing but indicated by the sharp decreases of both the 340 - and $380-\mathrm{nm}$ signals at $1,600 \mathrm{~s}$ of perfusion). The ratio values for the period of perfusion with $\mathrm{MnCl}_{2}$ have been deleted from the top tracing because they become noisy and are no longer meaningful as indices of $\mathrm{Ca}_{\mathrm{f}}$. 

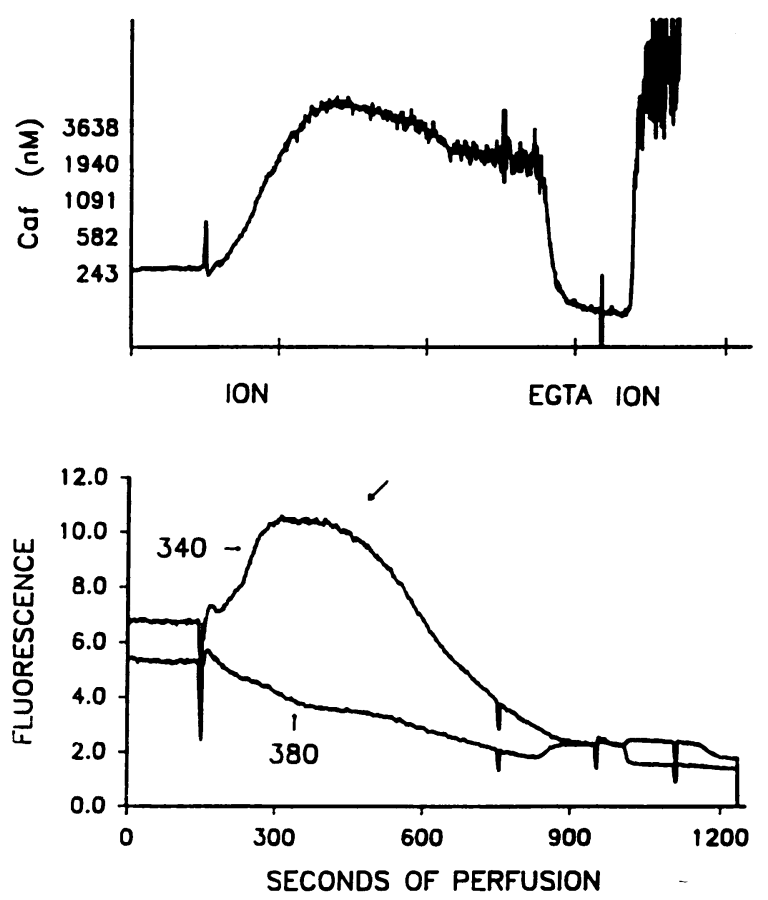

Figure 2. Behavior of $\mathrm{Ca}_{\mathrm{f}}$ in tubule treated with ionomycin. The tubule was perfused for $\sim 175 \mathrm{~s}$ under control conditions; then 10 $\mu \mathrm{M}$ ionomycin was introduced (first ION label under horizontal axis of top tracing). The calibration procedure was started at $\sim 750 \mathrm{~s}$ and was the same as detailed for Fig. 3. The large arrow in the bottom tracing of the raw 340- and 380-nm signals indicates the point at which the accelerated fura leak started.
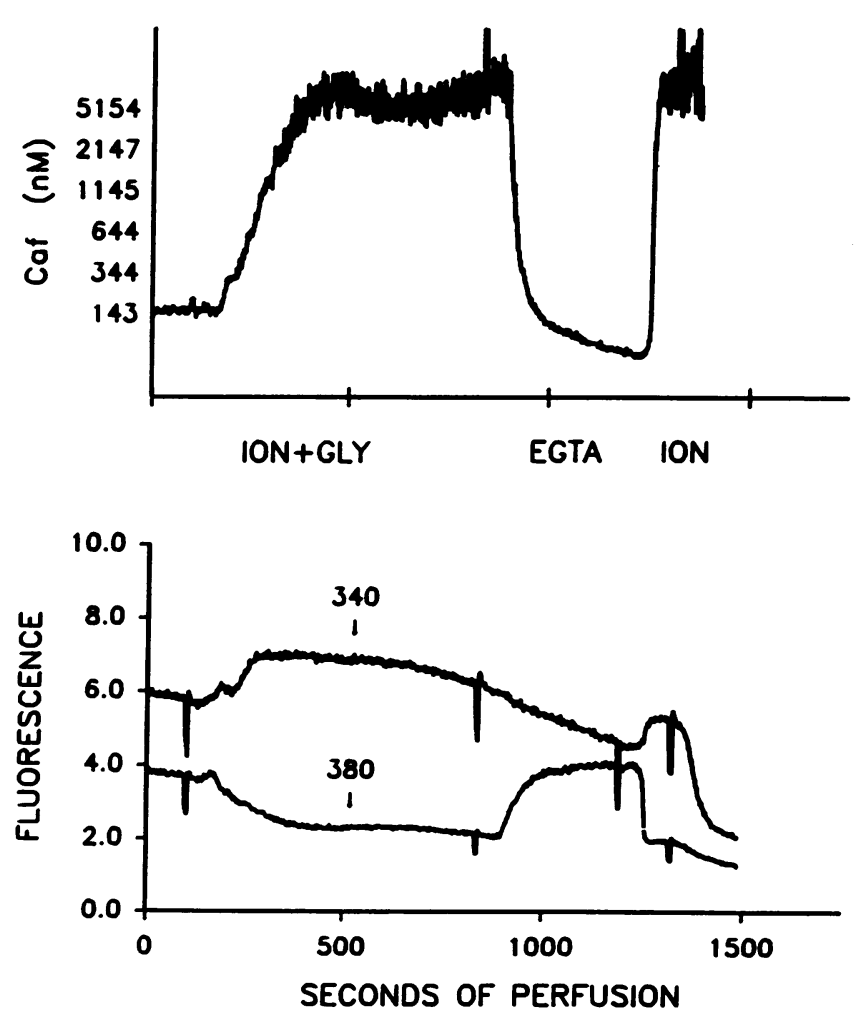

Figure 3. Behavior of $\mathrm{Ca}_{\mathrm{f}}$ in tubule treated with ionomycin plus glycine. The tubule was perfused for $\sim 100 \mathrm{~s}$ under control conditions then $15 \mu \mathrm{M}$ ionomycin $+2 \mathrm{mM}$ glycine was introduced (ION + GLY label under horizontal axis of top tracing). The terminal calibration procedure was the same as detailed for Fig. 3 . a parallel loss of intensity of both signals at an accelerated rate beginning shortly after the peak of $\mathrm{Ca}_{\mathrm{f}}$, indicating extensive leakage of the dye. Consistent with this, the changes of the raw signals induced by the calibration procedure are much smaller in magnitude than those of control cells that have not lost dye (Fig. 2). The ratios, however, still allow determination of the span of the $\mathrm{Ca}^{2+}$-sensitive fura response as in the control cells.

Fig. 3 illustrates the responses of a typical tubule treated with $15 \mu \mathrm{M}$ ionomycin in the presence of glycine. As in the tubule not treated with glycine (Fig. 2), ionomycin increased $\mathrm{Ca}_{\mathrm{f}}$ to the micromolar range. The main difference from the tubule not exposed to glycine is that the accelerated dye leak did not occur. Changes of the 340-and 380-nm signals induced by exposure to ionomycin were sustained until EGTA was introduced to start the calibration procedure. The calibration steps then produced large absolute changes of the signals much like those seen in control tubules, indicating excellent retention of fura by the cells.

Tubules treated with 1799 had a different pattern of behavior of $\mathrm{Ca}_{\mathrm{f}}$ than tubules treated with ionomycin. $\mathrm{Ca}_{\mathrm{f}}$ either remained unchanged for the 15-min exposure and accelerated leak of fura did not occur or, toward the end of the exposure, $\mathrm{Ca}_{\mathrm{f}}$ increased to the micromolar range and this was immediately followed by leak of fura. Fig. 4 shows a tubule of the latter type where the leak started just before the end of the $15-\mathrm{min}$ exposure to 1799 and continued during the calibration procedure. As a result, the amplitude of signal changes induced by the calibration maneuvers was diminished. Glycine-treated tubules also showed increases of $\mathrm{Ca}_{\mathrm{f}}$ in a delayed fashion after
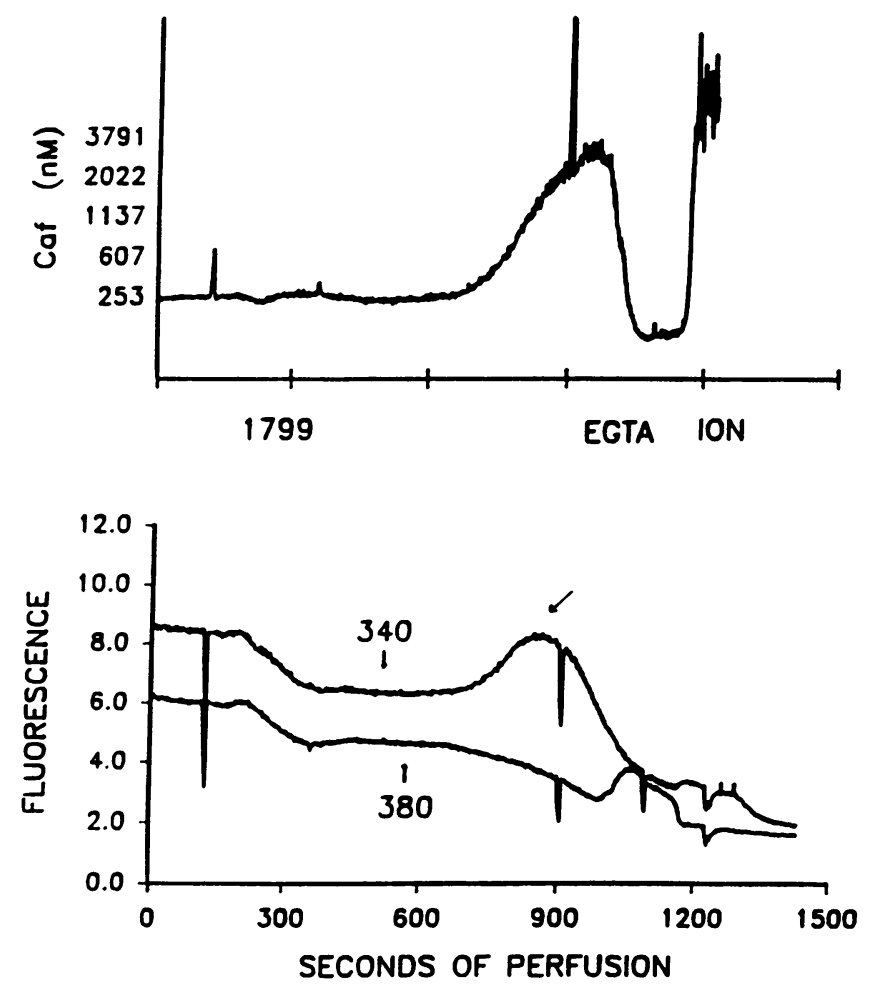

Figure 4. Behavior of $\mathrm{Ca}_{\mathrm{f}}$ in tubule treated with 1799. The tubule was perfused for $\sim 100 \mathrm{~s}$ under control conditions; then $20 \mu \mathrm{M} 1799$ was introduced (1799 label under horizontal axis of top tracing). The terminal calibration procedure was the same as detailed in Fig. 3. The large arrow in the bottom tracing of the raw 340- and 380-nm signals indicates the point at which the accelerated fura leak started. 
exposure to 1799 , but these were not followed by leakage of dye. Fig. 5 shows a 1799 + glycine-treated tubule which was studied the same day as the tubule treated with 1799 alone in Fig. 4 and which had an increase in $\mathrm{Ca}_{\mathrm{f}}$ at a similarly late time point during exposure to 1799 , just before the calibration procedure started. The absence of leakage before or during the calibration procedure is indicated by the large amplitude responses of the 340- and 380-nm signals to each of the calibration maneuvers (compare with effects of similar maneuvers in Fig. 4).

Tracings from tubules treated with ionomycin +1799 are not specifically illustrated because they were very similar to those from tubules treated with ionomycin alone. $\mathrm{Ca}_{\mathrm{f}}$ immediately rose upon exposure to the agents and this was closely followed by an accelerated leak in the absence of glycine, but not when glycine was present.

In a total of 41 experiments, including at least two or three for every injury and protection condition studied, instead of doing the calibration procedure at the end of the experiment, we interrupted the perfusion to assess Trypan exclusion by perfusion with medium containing $0.2 \%$ Trypan blue. We found that tubules perfused in the absence of 1799 or ionomycin never had more than one or two Trypan positive cells of the $30-40$ in the field covered by the photomultiplier. Tubules perfused with Trypan blue when both raw signals were rapidly decreasing had large numbers of Trypan-positive cells to the extent that virtually all cells were positive if Trypan was introduced when the signals had again plateaued at the end of the leak (e.g., $800 \mathrm{~s}$ in Fig. 2). In unprotected tubules that showed increases of $\mathrm{Ca}_{\mathrm{f}}$, the changes of $\mathrm{Ca}_{\mathrm{f}}$ started before cells began to turn Trypan positive, but substantial numbers of Trypan-positive cells began to appear as $\mathrm{Ca}_{\mathrm{f}}$ peaked. In protected tubules
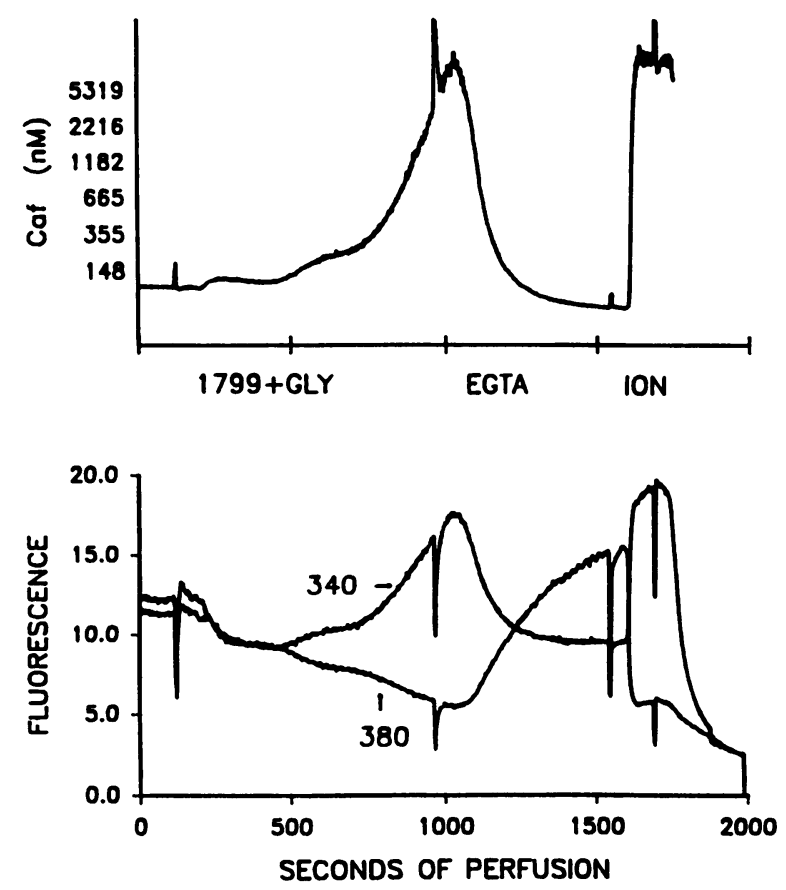

Figure 5. Behavior of $\mathrm{Ca}_{\mathrm{f}}$ in tubule treated with 1799 plus glycine. The tubule was perfused for $\sim 100 \mathrm{~s}$ under control conditions; then $20 \mu \mathrm{M} 1799+2 \mathrm{mM}$ glycine was introduced (1799 + GLY label under horizontal axis of top tracing). The terminal calibration procedure was the same as detailed for Fig. 3. that did not leak, Trypan-positive cells did not develop irrespective of increased $\mathrm{Ca}_{\mathbf{f}}$.

Table III summarizes the results of all studies in unprotected and glycine-protected tubules treated with ionomycin, 1799 , or ionomycin +1799 according to whether increases of $\mathrm{Ca}_{\mathrm{f}}$ or loss of viability defined by accelerated dye leak occurred during $15 \mathrm{~min}$ of exposure. Ionomycin increased $\mathrm{Ca}_{\mathrm{f}}$ to the micromolar level in all tubules studied and caused leakage of fura in seven of eight. 1799 increased $\mathrm{Ca}_{\mathrm{f}}$ in $55 \%$ of the tested tubules and all of these increases were to micromolar $\mathrm{Ca}_{\mathrm{f}}$ levels. All of the unprotected, 1799-treated tubules with increases of $\mathrm{Ca}_{\mathrm{f}}$ subsequently leaked fura as illustrated in Fig. 4. Glycine did not modify the increases of $\mathrm{Ca}_{\mathrm{f}}$ produced by either ionomycin or 1799 , but consistently prevented the leak of fura.

Effects of pH 6.9 on changes in tubule $\mathrm{Ca}_{f}$ and viability induced by ionomycin, 1799, and ionomycin +1799 . Perfusion of control tubules with pH 6.9 medium did not affect $\mathrm{Ca}_{\mathrm{f}}(\mathrm{Ta}-$ ble III). The increase of $\mathrm{Ca}_{\mathrm{f}}$ produced by ionomycin tended to be slowed at $\mathrm{pH} 6.9$, but still reached micromolar levels in every experiment (Fig. $6 \mathrm{~A}$ and Table III). Ionomycin +1799 produced a brisk increase of $\mathrm{Ca}_{\mathrm{f}}$ to maximal levels in every experiment at pH 6.9 (Fig. $6 \mathrm{~B}$ and Table III). Three of the six tubules studied with 1799 alone at pH 6.9 had increases of $\mathrm{Ca}_{\mathrm{f}}$ (Table III). pH 6.9 was highly protective against loss of viability as indicated by accelerated dye leak (Table III).

Effects of 1799 and ionomycin on injury to suspended tubules treated with $100 \mathrm{nM} \mathrm{Ca}{ }^{2+}$ medium. Reduction of me-

Table III. Development of Increased $\mathrm{Ca}_{f}$ and Accelerated Fura Leak or Failure to Exclude Trypan Blue by Superfused Proximal Tubules within $15 \mathrm{~min}$

\begin{tabular}{|c|c|c|}
\hline & $\begin{array}{c}\text { Fura leak } \\
\text { in } \leq 15 \mathrm{~min}\end{array}$ & $\begin{array}{c}\text { Increased } \\
\mathrm{Ca}_{\mathrm{f}}\end{array}$ \\
\hline Time control & $0 / 4$ & $0 / 4$ \\
\hline Time control at pH 6.9 & $0 / 4$ & $0 / 4$ \\
\hline Time control in $100 \mathrm{nM} \mathrm{Ca}^{2+}$ & $0 / 4$ & $0 / 4$ \\
\hline ION & $7 / 8$ & $8 / 8$ \\
\hline ION + 1799 & $8 / 10$ & $10 / 10$ \\
\hline 1799 & $6 / 11$ & $6 / 11$ \\
\hline ION $+2 \mathrm{mM}$ glycine & $0 / 11^{*}$ & $11 / 11$ \\
\hline ION $+1799+2 \mathrm{mM}$ glycine & $2 / 11^{*}$ & $11 / 11$ \\
\hline $1799+2 \mathrm{mM}$ glycine & $0 / 8^{*}$ & $5 / 8$ \\
\hline ION at pH 6.9 & $1 / 5^{*}$ & $5 / 5$ \\
\hline $\mathrm{ION}+1799$ at $\mathrm{pH} 6.9$ & $2 / 10^{*}$ & $10 / 10$ \\
\hline 1799 at $\mathrm{pH} 6.9$ & $0 / 6^{*}$ & $3 / 6$ \\
\hline $\mathrm{ION}$ in $100 \mathrm{nM} \mathrm{Ca}^{2+}$ & $0 / 5^{*}$ & $0 / 5^{*}$ \\
\hline $\mathrm{ION}+1799$ in $100 \mathrm{nM} \mathrm{Ca}^{2+}$ & $7 / 8$ & $0 / 8^{*}$ \\
\hline 1799 in $100 \mathrm{nM} \mathrm{Ca}^{2+}$ & $3 / 6$ & $0 / 6^{*}$ \\
\hline
\end{tabular}

The columns show the number of tubules which sustained lethal injury by the leak and Trypan exclusion criteria or had increases of $\mathrm{Ca}_{\mathrm{f}}$ to the micromolar range versus the total number of tubules studied in each group. Ionomycin (ION) and ION + 1799-treated groups included approximately equal numbers of tubules treated with 10 and $15 \mu \mathrm{M}$ ionomycin. Results did not differ at the two concentrations in the perfusion system. Data are pooled for conciseness of presentation.

${ }^{*} P<0.01$ vs. corresponding group not treated with glycine. 


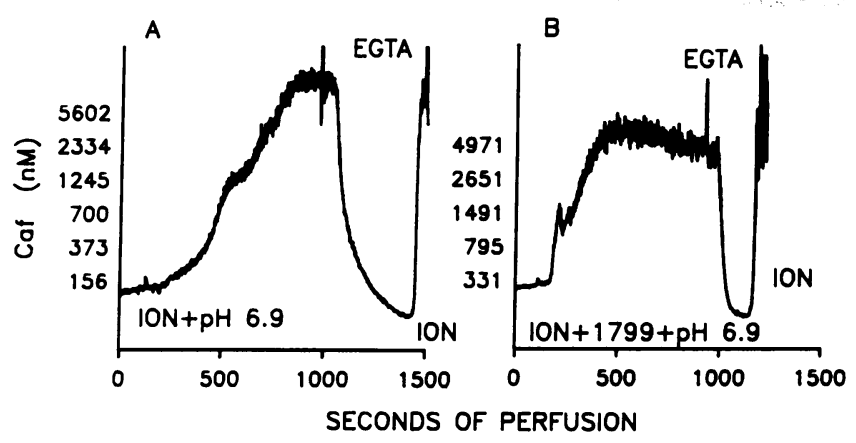

Figure 6. Behavior of $\mathrm{Ca}_{\mathrm{f}}$ in tubules exposed to $(A)$ ionomycin or $(B)$ ionomycin +1799 in $\mathrm{pH} 6.9$ medium. The tubules were perfused for $\sim 100 \mathrm{~s}$ under control conditions; then $15 \mu \mathrm{M}$ ionomycin or ionomycin $+20 \mu \mathrm{M} 1799$ in pH 6.9 medium was introduced. The terminal calibration procedure was the same as detailed for Fig. 3. Neither tubule leaked fura in the raw 340- and 380-nm tracings (not shown).

dium $\mathrm{Ca}^{2+}$ to $100 \mathrm{nM}$ by addition of EGTA simultaneously with ionomycin strongly ameliorated ionomycin-induced LDH release during $15 \mathrm{~min}$ of incubation (Fig. 7). At this duration, $100 \mathrm{nM} \mathrm{Ca}^{2+}$ medium did not have a significant effect on $\mathrm{LDH}$ release due to 1799 alone or the combination of ionomycin +1799 . However, a more detailed examination of the time course of these effects (Fig. 8) showed that reduction of medium $\mathrm{Ca}^{2+}$ to $100 \mathrm{nM}$ did have a substantial protective effect on tubules treated with ionomycin +1799 at 7.5 min of incubation. Changes of cell ATP induced by 1799 and ionomycin in these studies were generally similar to those detailed in Tables I and II and were not consistently altered by the reduction of medium $\mathrm{Ca}^{2+}$.

Effects of 1799 and ionomycin on $\mathrm{Ca}_{f}$ and viability of tu-

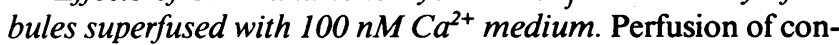
trol tubules with $100 \mathrm{nM} \mathrm{Ca}^{2+}$ medium gradually lowered $\mathrm{Ca}_{\mathrm{f}}$ (Fig. 9 A). A similar pattern was seen in tubules treated with ionomycin in $100 \mathrm{nM} \mathrm{Ca}^{2+}$ medium (Fig. 9 B). No leakage of dye occurred in under either of these conditions (Table III). Tubules treated with $10 \mu \mathrm{M}$ ionomycin +1799 in $100 \mathrm{nM} \mathrm{Ca}^{2+}$

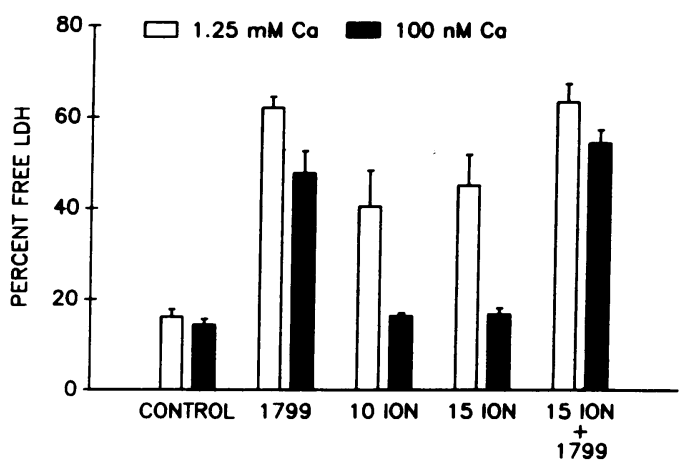

Figure 7. Effects of reducing medium $\mathrm{Ca}^{2+}$ to $100 \mathrm{nM}$ on $\mathrm{LDH}$ release induced by 1799 and ionomycin. Tubules were exposed to $20 \mu \mathrm{M}$ $1799,10 \mu \mathrm{M}$ ionomycin (10 ION), $15 \mu \mathrm{M}$ ionomycin (15 ION) or $15 \mu \mathrm{M}$ ionomycin plus $20 \mu \mathrm{M} 1799$ for $15 \mathrm{~min}$ in the regular medium containing $1.25 \mathrm{mM} \mathrm{Ca}^{2+}$ or in medium buffered with EGTA to 100 $\mathrm{nM} \mathrm{Ca}{ }^{2+}$. Values are means $\pm \mathrm{SE}$ of results from four experiments. $P$ $<0.05$ for both 10 and $15 \mu \mathrm{M}$ ionomycin in $100 \mathrm{nM} \mathrm{Ca}^{2+}$ vs. 1.25 $\mathrm{mM} \mathrm{Ca}{ }^{2+}$. Tubules for these experiments were not fura-loaded and medium was probenecid-free.

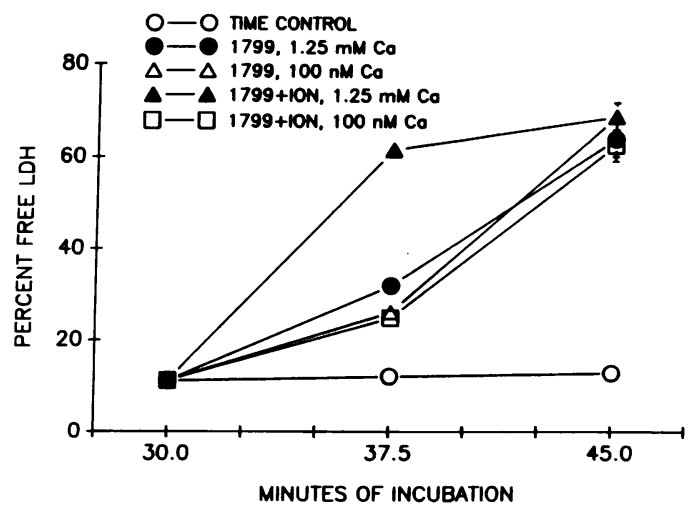

Figure 8. Time course of LDH release induced by 1799 or ionomycin +1799 in the presence of $1.25 \mathrm{mM}$ and $100 \mathrm{nM}$ medium $\mathrm{Ca}^{2+}$. Tubules were treated at 30 min of incubation with $20 \mu \mathrm{M} 1799$ or with $15 \mu \mathrm{M}$ ionomycin plus $20 \mu \mathrm{M} 1799$ in the regular medium containing $1.25 \mathrm{mM} \mathrm{Ca}^{2+}$ or in medium buffered with EGTA to maintain a constant $\mathrm{Ca}^{2+}$ of $100 \mathrm{nM}$. Samples for $\mathrm{LDH}$ release were taken after $7.5 \mathrm{~min}$ of exposure at $37.5 \mathrm{~min}$ of incubation and after $15 \mathrm{~min}$ of exposure at $45 \mathrm{~min}$ of incubation. Values are means $\pm \mathrm{SE}$ of results from three experiments. SE not drawn were smaller than the symbols for those points. $P<0.01$ for all toxin-treated groups vs. time controls at 37.5 and $45 \mathrm{~min} . P<0.01$ for $1799+$ ionomycin tubules in $1.25 \mathrm{mM} \mathrm{Ca}^{2+}$ medium vs. $100 \mathrm{nM} \mathrm{Ca}^{2+}$ medium at 37.5 $\mathrm{min}$. Tubules for these experiments were not fura-loaded and medium was probenecid-free.

medium also did not show increases of $\mathrm{Ca}_{\mathrm{f}}$ (Fig. 10), however in all but one experiment, dye leakage occurred during $15 \mathrm{~min}$ of exposure to ionomycin +1799 (Fig. 10 and Table III). In the four studies using $15 \mu \mathrm{M}$ ionomycin +1799 , where all tubules leaked within $15 \mathrm{~min}$ in both $1.25 \mathrm{mM} \mathrm{Ca}^{2+}$ and $100 \mathrm{nM} \mathrm{Ca}^{2+}$ media, the time to leakage in $100 \mathrm{nM} \mathrm{Ca}^{2+}$ medium, $549.3 \pm 50.1 \mathrm{~s}$ was significantly $(P<0.01)$ longer than in 1.25 $\mathrm{mM} \mathrm{Ca}^{2+}$ medium, 288.5 $\pm 24.2 \mathrm{~s}$. Tubules treated with 1799 alone in $100 \mathrm{nM} \mathrm{Ca}^{2+}$ medium displayed either no change of $\mathrm{Ca}_{\mathrm{f}}$ or, in three of the six studies, a gradual, small amplitude, $\mathrm{Ca}^{2+}$ transient as illustrated in Fig. 11. Half the tubules treated with 1799 in $100 \mathrm{nM} \mathrm{Ca}^{2+}$ medium leaked during the $15 \mathrm{~min}$ of incubation (Table III).

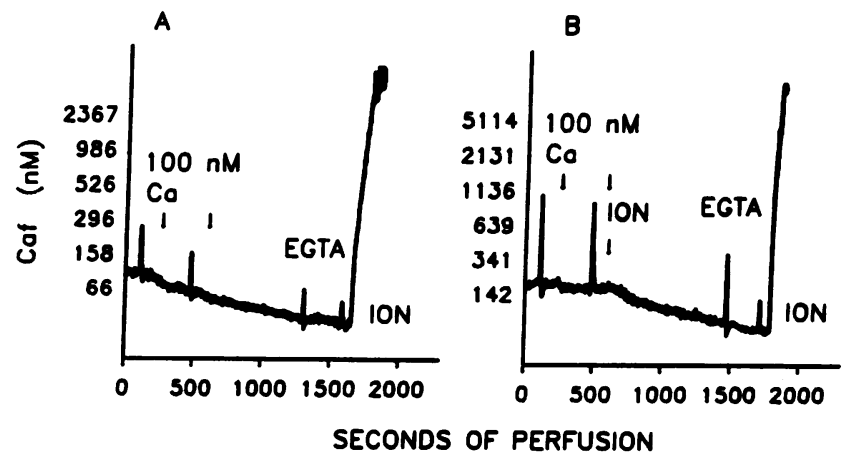

Figure 9. Behavior of $\mathrm{Ca}_{\mathrm{f}}$ in tubules exposed to $100 \mathrm{nM} \mathrm{Ca}^{2+}$ medium. The tubules were perfused for $\sim 100 \mathrm{~s}$ under control conditions, then with $100 \mathrm{nM} \mathrm{Ca}^{2+}$ medium for $400 \mathrm{~s}$ followed in $A$ by an additional 900 -s perfusion with $100 \mathrm{nM} \mathrm{Ca}^{2+}$ medium from a second syringe and in $B$ by an additional 900 -s perfusion with 15 $\mu \mathrm{M}$ ionomycin in $100 \mathrm{nM} \mathrm{Ca}^{2+}$ medium. The terminal calibration procedure was the same as detailed for Fig. 3. Neither tubule leaked fura in the raw 340- and 380-nm tracings (not shown). 

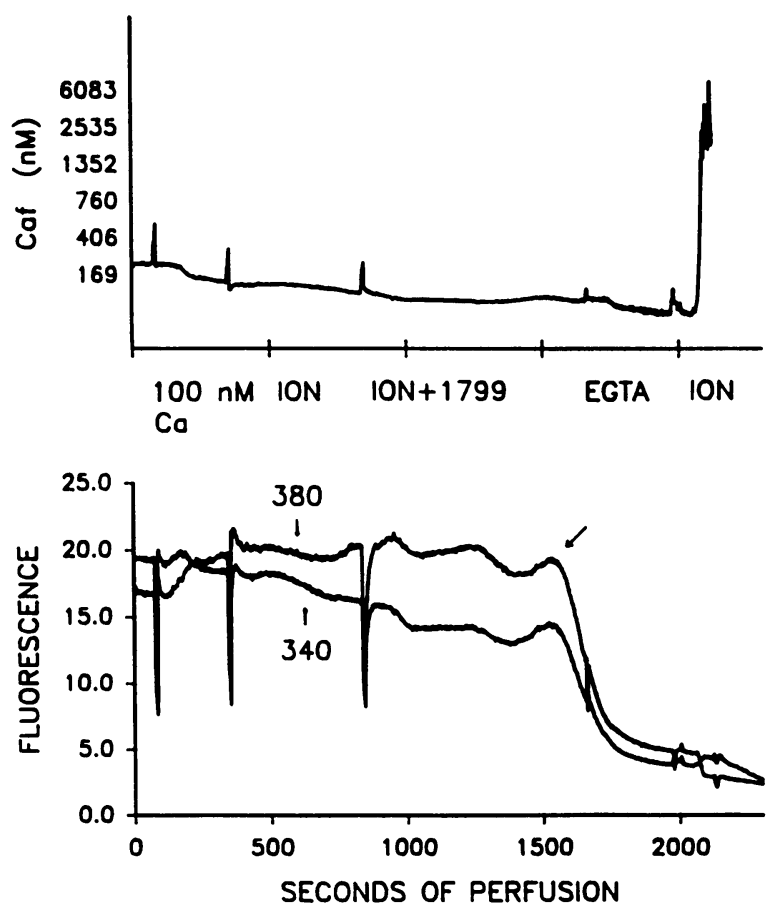

Figure 10. Effect of ionomycin +1799 on $\mathrm{Ca}_{\mathrm{f}}$ in $100 \mathrm{nM} \mathrm{Ca}^{2+}$ medium. The tubule was perfused for $\sim 100 \mathrm{~s}$ under control conditions then with $100 \mathrm{nM} \mathrm{Ca}^{2+}$ medium for $300 \mathrm{~s}$ followed by 10 $\mu \mathrm{M}$ ionomycin $(I O N)$ in $100 \mathrm{nM} \mathrm{Ca}^{2+}$ medium, then $10 \mu \mathrm{M}$ ionomycin plus $20 \mu \mathrm{M} 1799$ in $100 \mathrm{nM} \mathrm{Ca}^{2+}$ medium. All of our initial $10 \mu \mathrm{M}$ ionomycin +1799 studies summarized in Table III were done with an initial exposure to $10 \mu \mathrm{M}$ ionomycin alone as in this experiment. Subsequent $15 \mu \mathrm{M}$ ionomycin +1799 studies were done with similar results by immediately introducing the ionomycin +1799 after the preliminary $100 \mathrm{nM} \mathrm{Ca}^{2+}$ medium perfusion. The terminal calibration procedure was the same as detailed for Fig. 3 . The large arrow in the bottom tracing of the raw 340- and 380-nm signals indicates the point at which the accelerated fura leak started.

\section{Discussion}

These data delineate in detail behavior of $\mathrm{Ca}_{\mathrm{f}}$ in well-defined models of injury to the fully differentiated, freshly isolated, proximal tubule. Furthermore, the results show that glycine and reduced $\mathrm{pH}$ protect against lethal cell injury associated with increases of $\mathrm{Ca}_{\mathrm{f}}$ to the micromolar level irrespective of whether these increases occur as a late, prelethal consequence of treatment with an uncoupler of mitochondrial oxidative phosphorylation or are induced by high concentrations of a $\mathrm{Ca}^{2+}$ ionophore.

Mutually reinforcing and generally consistent data were obtained from three complementary experimental conditions: fura-loaded tubules studied in probenecid-containing medium in suspension, fura-loaded tubules studied singly while being superfused with probenecid-containing medium, and unloaded tubules studied in suspension in the absence of probenecid. Despite the different physical characteristics of the systems, the progression to lethal cell injury was comparable in the superfused and suspended cells, suggesting that changes in parameters such as cell ATP which could not be readily assessed in the superfusion system can be confidently inferred from the behavior of the suspended tubules. Although some quantitative differences of injury parameters between fura-loaded cells
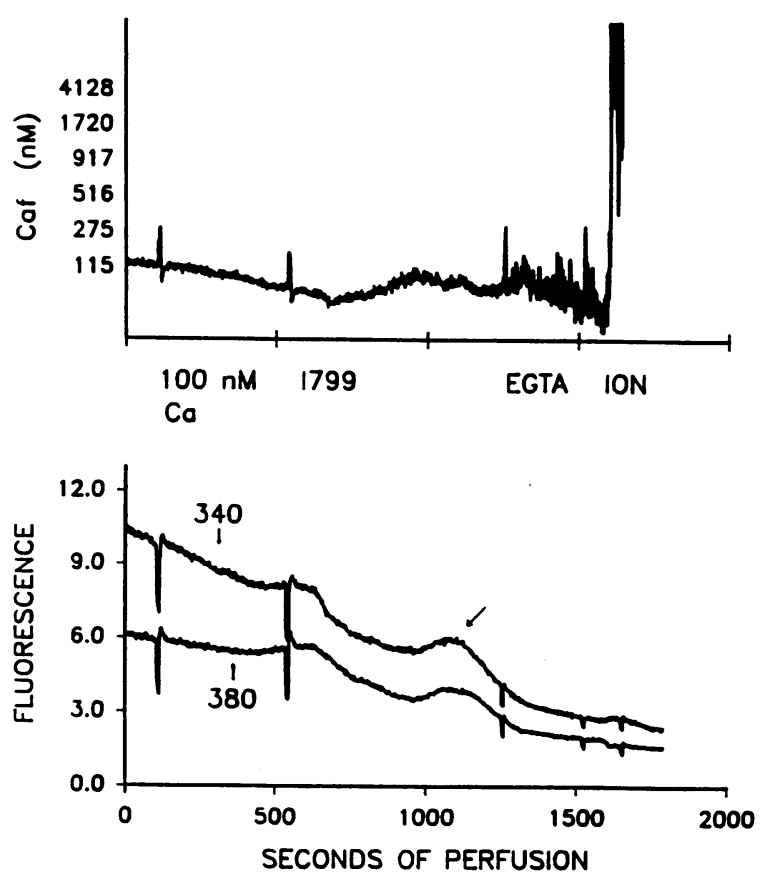

Figure 11. Effect of 1799 on $\mathrm{Ca}_{\mathrm{f}}$ in $100 \mathrm{nM} \mathrm{Ca}^{2+}$ medium. The tubule was perfused for $\sim 100 \mathrm{~s}$ under control conditions then with 100 $\mathrm{nM} \mathrm{Ca}{ }^{2+}$ medium for $400 \mathrm{~s}$ followed by $20 \mu \mathrm{M} 1799$ in $100 \mathrm{nM} \mathrm{Ca}^{2+}$ medium. The terminal calibration procedure was the same as detailed for Fig. 3. The large arrow in the bottom tracing of the raw 340- and 380-nm signals indicates the point at which the accelerated fura leak started.

studied in the presence of probenecid and unloaded cells in probenecid-free medium were found, the experimental conditions required for determination of $\mathrm{Ca}_{\mathrm{f}}$ did not alter the major patterns of injury responses or protective effects.

It has previously been reported $(17,18,41,42)$ that accelerated leakage of cytosolic fluorescent probes accompanies the type of plasma membrane damage that results in failure to exclude vital dyes, a generally accepted criterion of lethal cell injury. Our results showing a close temporal association between accelerated fura leakage and loss of ability to exclude Trypan blue indicate that the tubules behaved similarly over the time frame of our studies. This phenomenon provided a sensitive way of timing the onset of lethal cell injury from the same measurements used for determination of $\mathrm{Ca}_{\mathrm{f}}$.

Our data represent the averaged responses of 30-40 tubule cells in the field covered by the photomultiplier. Thus, intermediate changes of $\mathrm{Ca}_{\mathrm{f}}$ or of levels of dye loading could indicate uniform, partial effects in many cells or a combination of severe effects in some cells and none in others. However, under virtually all the experimental conditions studied, the tubules developed maximal alterations of $\mathrm{Ca}_{\mathrm{f}}$ and dye retention relatively rapidly once changes began and similarly rapid loss of ability to exclude Trypan blue also was seen. This suggests a high degree of synchrony between individual tubule cells.

Although delayed in the 1799-treated cells, increases of $\mathrm{Ca}_{\mathrm{f}}$ to micromolar levels consistently occurred before lethal cell injury. However, injury was not ameliorated when these increases of $\mathrm{Ca}_{\mathrm{f}}$ were prevented by incubation in medium with $\mathrm{Ca}^{2+}$ buffered to $100 \mathrm{nM}$. These observations are like those previously reported by Nieminen et al. (17) and by Lemasters 
and co-workers (18) in studies of single cultured hepatocytes that were ATP-depleted and injured by treatment with cyanide + iodoacetate. The prevention of increases in $\mathrm{Ca}_{\mathrm{f}}$ by $100 \mathrm{nM}$ $\mathrm{Ca}^{2+}$ medium indicates that extracellular $\mathrm{Ca}^{2+}$ is primarily responsible for them. Whether equivalent changes of $\mathrm{Ca}_{\mathrm{f}}$ occur in other types of ATP depletion-induced proximal tubule injury remains to be determined. However, the similarity of the LDH release and ATP depletion responses of the 1799-treated tubules in this study to those seen in the proximal tubule system with a variety of other ATP-depleting mitochondrial inhibitors and hypoxia (23-26) makes it likely that the present observations of $\mathrm{Ca}_{\mathrm{f}}$ alterations will be of generalized applicability.

By consistently, rapidly increasing $\mathrm{Ca}_{\mathrm{f}}$ to the micromolar range, ionomycin, as used in the present study, provided a valuable tool for further assessing the potential for increased $\mathrm{Ca}_{\mathrm{f}}$ to contribute to tubule cell injury. Although relatively high concentrations of ionomycin were required to produce toxic effects in the fresh tubules, these were specific actions of ionomycin related to increases of $\mathrm{Ca}_{\mathrm{f}}$ because toxicity did not occur when the increases of $\mathrm{Ca}_{\mathrm{f}}$ were prevented by buffering medium $\mathrm{Ca}^{2+}$ at $100 \mathrm{nM}$. This was true regardless of whether ionomycin was used alone or in combination with 1799 and is similar to previous reports on the $\mathrm{Ca}^{2+}$ dependence of $\mathrm{Ca}^{2+}$ ionophoreinduced injury in other cell types $(15,43,44)$. Although severe reductions of medium $\mathrm{Ca}^{2+}$ can be toxic to isolated cells, including tubule cells $(45,46)$, this was not a problem with the durations of exposure used for the present work.

Selective protection by $100 \mathrm{nM} \mathrm{Ca}^{2+}$ against ionomycin-induced but not against 1799-induced injury is particularly evident from the studies of ionomycin +1799 in combination. There, $100 \mathrm{nM} \mathrm{Ca}^{2+}$ shifted the timing of damage from the very rapid pattern seen with ionomycin +1799 in $1.25 \mathrm{mM} \mathrm{Ca}^{2+}$ to the slower pattern seen with 1799 alone, but, unlike glycine and reduced $\mathrm{pH}$, did not substantially protect throughout the interval studied.

The requirement for high concentrations of ionomycin to maximally increase tubule $\mathrm{Ca}_{\mathrm{f}}$ probably reflects active tubule cell $\mathrm{Ca}^{2+}$ extrusion mechanisms rather than a low sensitivity to the ionophore. ATP was partially preserved in tubules treated with ionomycin alone and the relatively high $\mathrm{K}^{+}$content of those tubules indicates retention of sodium pump activity. This would allow continued $\mathrm{Ca}^{2+}$ extrusion by ionomycin-treated cells via both $\mathrm{Ca}^{2+}$-ATPases and $\mathrm{Na}^{+} / \mathrm{Ca}^{2+}$ exchange $(47,48)$.

Protection by glycine and reduction of $\mathrm{pH}$ to 6.9 in the present studies is similar to that which has been described during hypoxia-, ouabain-, and metabolic inhibitor-induced tubule cell injury (23-28). Our results indicate that both glycine and $\mathrm{pH} 6.9$ have major protective actions irrespective of whether the increases of $\mathrm{Ca}_{\mathrm{f}}$ occur rapidly in response to ionomycin or as a delayed effect of uncoupler-induced ATP depletion. The ionomycin +1799 groups provide a condition in which both profound ATP depletion and maximal increases of $\mathrm{Ca}_{\mathrm{f}}$ were particularly rapid, yet protection was clearly evident.

Decreased transmembrane $\mathrm{Ca}^{2+}$ fluxes have been suggested as a mechanism for the protective effects of reduced $\mathrm{pH}(24$, 49) and $\mathrm{pH} 6.9$ medium did tend to delay the $\mathrm{Ca}_{\mathrm{f}}$ increase produced by ionomycin alone. However, this likely relates to the direct effects of $\left[\mathrm{H}^{+}\right]$on ionomycin activity $(50)$ and cannot account for the major protection provided by reduced $\mathrm{pH}$ once $\mathrm{Ca}_{\mathrm{f}}$ did increase.

The protective effects of glycine occur in spite of equivalent or even more severe decreases of ATP and glutathione in gly- cine-protected cells than in unprotected cells (Table II and references $25,26,29$, and 30 ), indicating that glycine acts on a process distal to these major events in the development of cell injury. The present studies demonstrate that increased $\mathrm{Ca}_{\mathrm{f}}$ is another of the classical mediators of cell injury whose ultimate deleterious action to compromise tubule cell viability is blocked by glycine and suggest that further examination of the effects of glycine an $\mathrm{Ca}^{2+}$-mediated degradative processes may be informative with regard to the amino acid's ultimate mechanism of protection.

\section{Acknowledgments}

We thank Dr. Peter Heytler for kindly supplying the 1799. The assistance of Magaly Abarzua, Sandra Schultz, Uta Hussong, Sujatha Sastry, Adhir Shroff, and Tracy Jenkins was invaluable.

This work was supported by National Institutes of Health (NIH) grants DK-34275 and DK-39255, the Veterans Administration, the National Kidney Foundation of Michigan (to Dr. Weinberg) and NIH grants DK-37139 and DK-17387 (to Dr. Venkatachalam).

\section{References}

1. Carafoli, E. 1987. Intracellular calcium homeostasis. Annu. Rev. Biochem. $56: 395-433$

2. Farber, J. L. 1982. Biology of disease: membrane injury and calcium homeostasis in the pathogenesis of coagulative necrosis. Lab. Invest. 47:114-123.

3. Trump, B. F., and I. K. Berezesky. 1985. The role of calcium in cell injury and repair: a hypothesis. Surv. Synth. Pathol. Res. 4:248-256.

4. Orrenius, S., and P. Nicotera. 1987. On the role of calcium in chemical toxicity. Arch. Toxicol. Suppl. 11:11-19.

5. Thomas, C. E., and D. J. Reed. 1989. Current status of calcium in hepatocellular injury. Hepatology (Baltimore). 10:375-384.

6. Weinberg, J. M. 1984. Calcium as a mediator of renal tubule cell injury. Semin. Nephrol. 4:179-191.

7. Schrier, R. W., P. E. Arnold, V. J. Van Putten, and T. J. Burke. 1987. Cellular calcium in ischemic acute renal failure: role of calcium entry blockers. Kidney Int. 32:313-321.

8. Cheung, J. Y., J. V. Bonventre, C. D. Malis, and A. Leaf. 1986. Calcium and ischemic injury. N. Engl. J. Med. 314:1670-1676.

9. Weinberg, J. M., and H. D. Humes. 1985. Calcium transport and inner mitochondrial membrane damage in renal cortical mitochondria. Am. J. Physiol. 248:F876-F889.

10. Weinberg, J. M., P. G. Harding, and H. D. Humes. 1983. Alterations in renal cortex cation homeostasis during mercuric chloride and gentamicin nephrotoxicity. Exp. Mol. Pathol. 39:43-60.

11. Arnold, P. E., D. Lumlertgul, T. J. Burke, and R. W. Schrier. 1985. In vitro versus in vivo mitochondrial calcium loading in ischemic acute renal failure. Am. J. Physiol. 248:F845-F850.

12. LeFurgey, A., P. Ingram, and L. J. Mandel. 1986. Heterogeneity of calcium compartmentation: electron probe analysis of renal tubules. J. Membr Biol. 94:191-196.

13. Snowdowne, K. W., C. C. Freudenrich, and A. B. Borle. 1985. The effects of anoxia on cytosolic free calcium, calcium fluxes, and cellular ATP levels in cultured kidney cells. J. Biol. Chem. 260:11619-11626.

14. McCoy, C. E., A. M. Selvaggio, E. A. Alexander, and J. H. Schwartz. 1988. Adenosine triphosphate depletion induces a rise in cytosolic free calcium in canine renal epithelial cells. J. Clin. Invest. 82:1326-1332.

15. Phelps, P. C., M. W. Smith, and B. F. Trump. 1989. Cytosolic ionized calcium and bleb formation after acute cell injury of cultured rabbit renal tubule cells. Lab. Invest. 60:630-642.

16. Mandel, L. J., and E. Murphy. 1984. Regulation of cytosolic free calcium in rabbit proximal renal tubules. J. Biol. Chem. 259:11188-11196.

17. Nieminen, A.-L., G. J. Gores, B. E. Wray, Y. Tanaka, B. Herman, and J. J. Lemasters. 1988. Calcium dependence of bleb formation and cell death in hepatocytes. Cell Calcium. 9:237-246.

18. Lemasters, J. J., J. DiGuiseppi, A. L. Nieminen, and B. Herman. 1987. Blebbing, free $\mathrm{Ca} 2+$ and mitochondrial membrane potential preceding cell death in hepatocytes. Nature (Lond.). 325:78-81.

19. Nicotera, P., H. Thor, and S. Orrenius. 1989. Cytosolic-free $\mathrm{Ca} 2+$ and cell killing in hepatoma $1 \mathrm{clc} 7$ cells exposed to chemical anoxia. FASEB (Fed. Am. Soc. Exp. Biol.) J. 3:59-64.

20. Li, Q., C. M. Hohl, R. A. Altschuld, and B. T. Stokes. 1989. Energy 
depletion-repletion and calcium transients in single cardiomyocytes. Am. J. Physiol. 257:C427-C434.

21. Morris, A. C., H. K. Hagler, J. T. Willerson, L. M. Buja, D. Bellotto, D. Buja, and B. Ziman. 1989. Relationship between calcium loading and impaired energy metabolism during $\mathrm{Na}^{+}, \mathrm{K}^{+}$pump inhibition and metabolic inhibition in cultured neonatal rat cardiac myocytes. J. Clin. Invest. 83:1876-1887.

22. Venkatachalam, M. A. 1981. Pathology of acute renal failure. In Acute Renal Failure. B. M. Brenner and J. H. Stein, editors. Churchill Livingstone, New York. 99-107.

23. Weinberg, J. M., J. A. Davis, M. Abarzua, and T. Rajan. 1987. Cytoprotective effects of glycine and glutathione against hypoxic injury to renal tubules. $J$. Clin. Invest. 80:1446-1454.

24. Weinberg, J. M. 1985. Oxygen deprivation-induced injury to isolated rabbit kidney tubules. J. Clin. Invest. 76:1193-1208.

25. Weinberg, J. M., J. A. Davis, M. Abarzua, and T. Kiani. 1989. Relationship between cell ATP and glutathione content and protection by glycine against hypoxic proximal tubule cell injury. J. Lab. Clin. Med. 113:612-623.

26. Weinberg, J. M., J. A. Davis, M. Abarzua, and T. Kiani. 1990. Glycine-dependent protection of proximal tubules against lethal cell injury due to inhibitors of mitochondrial ATP production. Am. J. Physiol. 258:C1127-C1140.

27. Weinberg, J. M., J. A. Davis, M. Abarzua, R. K. Smith, and R. Kunkel. 1990. Ouabain-induced lethal proximal tubule cell injury is prevented by glycine Am. J. Physiol. 258:F346-F355.

28. Weinberg, J. M., and J. A. Davis. 1990. A comparison between protection by glycine, acidosis and mannitol against proximal tubule cell injury. Clin. Res. 38:577A. (Abstr.)

29. Garza-Quintero, R., J. Ortega-Lopez, J. H. Stein, and M. A. Venkatachalam. 1990. Alanine protects rabbit proximal tubules against anoxic injury in vitro. Am. J. Physiol. 258:F1075-F1083.

30. Mandel, L. J., R. G. Schnellmann, and W. R. Jacobs. 1990. Intracellular glutathione in the protection from anoxic injury in renal proximal tubules. $J$ Clin. Invest. 85:316-324.

31. Steinberg, T. H., A. S. Newman, J. A. Swanson, and S. C. Silverstein. 1987. Macrophages possess probenecid-inhibitable organic anion transporters that remove fluorescent dyes from the cytoplasmic matrix. J. Cell Biol. 105:2695-2702.

32. Ullrich, K. J., and G. Rumrich. 1990. Interaction of prostoglandins and second messengers (cAMP, cGMP and derivatives) with contraluminal paraaminohippurate (PAH) transport system in the proximal renal tubule. Kidney Int 37:591. (Abstr.)

33. Merritt, J. E., R. Jacob, and T. J. Hallam. 1989. Use of manganese to discriminate between calcium influx and mobilization from internal stores in stimulated human neutrophils. J. Biol. Chem. 264:1522-1527.

34. Grynkiewicz, G., M. Poenie, and R. Y. Tsien. 1985. A new generation of $\mathrm{Ca}^{2+}$ indicators with greatly improved fluorescence properties. J. Biol. Chem. 260:3440-3450.

35. Davis, M. H., R. A. Altschuld, D. W. Jung, and G. P. Brierley. 1987.
Estimation of intramitochondrial $\mathrm{pCa}$ and $\mathrm{pH}$ by fura- 2 and 2,7 biscarboxyethyl5-(6)-carboxyfluorescein (BCECF) fluorescence. Biochem. Biophys. Res. Commun. 149:40-45.

36. Becker, G. L., G. Fiskum, and A. L. Lehninger. 1980. Regulation of free calcium by liver mitochondria and endoplasmic reticulum. J. Biol. Chem. 255:9009-9012.

37. Lowry, O. H., A. L. Rosebrough, A. L. Farr, and R. J. Randall. 1951. Protein measurement with folin phenol reagent. J. Biol. Chem. 193:265-275.

38. Harris, S. I., R. S. Balaban, L. Barrett, and L. J. Mandel. 1981. Mitochondrial respiratory capacity and $\mathrm{Na}^{+}$- and $\mathrm{K}^{+}$-dependent adenosine triphosphatasemediated ion transport in the intact renal cell. J. Biol. Chem. 256:10319-10328.

39. Heytler, P. G. 1979. Uncouplers of oxidative phosphorylation. Methods Enzymol. 55:462-472.

40. Fabiato, A. 1988. Computer programs for calculating total from specified free or free from specific total ionic concentrations in aqueous solutions containing multiple metals and ligands. Methods Enzymol. 157:378-417.

41. Kobler, M. A., R. R. Quinones, R. E. Gress, and P. A. Henkart. 1988. Measurement of cytotoxicity by target cell release and retention of the fluorescent dye bis-carboxyethyl-carboxyfluorescein (BCECF). J. Immunol. Methods 108:255-264.

42. Gores, G. J., A.-L. Nieminen, B. E. Wray, B. Herman, and J. J. Lemasters. 1989. Intracellular pH during "chemical hypoxia" in cultured rat hepatocytes: protection by intracellular acidosis against the onset of cell death. J. Clin. Invest. 83:386-396.

43. Schanne, F. A., A. B. Kane, E. E. Young, and J. L. Farber. 1979. Calcium dependence of toxic cell death: a final common pathway. Science (Wash. DC). 206:700-702.

44. Chenery, R., M. George, and G. Krishna. 1981. The effect of ionophore A23187 and calcium on carbon tetrachloride-induced toxicity in cultured rat hepatocytes. Toxicol. Appl. Pharmacol. 60:241-252.

45. Davis, J. A., and J. M. Weinberg. 1988. Effects of glycine and GSH on toxic maneuvers altering tubule cell plasma membrane cation permeability. Clin. Res. 36:517A. (Abstr.)

46. Fariss, M. W., G. A. Pascoe, and D. J. Reed. 1985. Vitamin E reversal of the effect of extracellular calcium on chemically induced toxicity in hepatocytes. Science (Wash. DC). 227:751-754.

47. Snowdowne, K. W., and A. B. Borle. 1985. Effects of low extracellular sodium on cytosolic ionized calcium: $\mathrm{Na}^{+}-\mathrm{Ca}^{2+}$ exchange as a major calcium influx pathway in kidney cells. J. Biol. Chem. 260:14998-15007.

48. Dominguez, J. H. J. K. Rothrock, W. L. Macias, and J. Price. $1989 . \mathrm{Na}^{+}$ electrochemical gradient and $\mathrm{Na}^{+}-\mathrm{Ca}^{2+}$ exchange in rat proximal tubule. Am. J. Physiol. 257:F531-F538.

49. Altschuld, R. A., J. R. Hostetler, and G. P. Brierley. 1981. Response of isolated heart cells to hypoxia, reoxygenation and acidosis. Circ. Res. 49:307316.

50. Liu, C., and T. E. Hermann. 1978. Characterization of ionomycin as a calcium ionophore. J. Biol. Chem. 253:5892-5894. 